Special Issue on Migration and Globalization, Canadian Studies in Population

Vol. 29(1), 2002, pp. 123-149

\title{
Socio-Demographic Aspects of Globalization: Canadian Perspectives on Migration
}

\author{
Anthony H. Richmond \\ Emeritus Professor of Sociology \\ York University, Toronto
}

\section{Abstract}

Trends in Canadian immigration and emigration in the last decade are examined, distinguishing 'temporary' and 'permanent' movements, economic migrants and refugees. Comparisons are made with those of other OECD countries. Global migration patterns have changed as a result of post-industrial technologies. Although money, goods and services may move relatively freely, people do not. Processes of inclusion and exclusion occur within and between countries and regions. A typology of migrant incorporation is presented. Questions of human security and border controls are considered. Recommendations are made concerning the protection of migrant human rights.

Key Words: Global, migration, transilient, refugee, temporary/permanent, security, rights. 
Anthony H. Richmond

\section{Résumé}

Trends in Canadian immigration and emigration in the last decade are examined, distinguishing 'temporary' and 'permanent' movements, economic migrants and refugees. Comparisons are made with those of other OECD countries. Global migration patterns have changed as a result of post-industrial technologies. Although money, goods and services may move relatively freely, people do not. Processes of inclusion and exclusion occur within and between countries and regions. A typology of migrant incorporation is presented. Questions of human security and border controls are considered. Recommendations are made concerning the protection of migrant human rights.

Key Words: Global, migration, transilient, refugee, temporary/permanent, security, rights.

\section{Introduction}

This article addresses the question whether Canada, and other advanced industrial societies, are opening or closing their doors as a consequence of globalization. It includes a discussion of recent concerns regarding border security. Canada is traditionally a country of immigration. In terms of the proportion of its population that is foreign-born (16.2\% in 1996), it is exceeded only by Australia (21.1\%) and Switzerland (19.0\%). However, global population movements have changed in recent decades. As a result, countries that were once noted for emigration, such as Italy, are now net gainers of population due to a combination of temporary and permanent migrants ${ }^{1}$. European migration includes categories variously described as 'transit migration', 'incompletemigration', 'migrant trafficking', 'petty trading', 'labour tourism', etc. (Salt, 2001:86). Migrant trafficking has increased as well as the efforts to controlit. Salt concluded "...these movements, including those which we have always assumed to be international migration, can be considered as the component parts of a world-wide industry, consisting of a series of businesses where it is possible to identify vested interests which seek to develop, manage and promote migration flows." (ibid: 106) 
Through net migration, the European Union gained 1.4 million people in 1992, following the collapse of communism. The largest gains were in Germany, Italy and the United Kingdom. However, net migration gains to the European Union fell to 400,000 by 1998 (Visco, 2000:4-6). As the total population of the European Union is approximately 375 million, this represented a net gain by migration of 1.2 per thousand, compared with a gain of 0.8 per thousand from natural increase. This contrasts with Canada, in 1998-99, where gains of 3.9 per thousand from natural increase and 4.1 per thousand from net migration were recorded (Statistics Canada, 2000). Although Canada's rates of growth from both natural increase and net migration remain much higher than that of most European countries, both rates have declined in the last decade.

In 1998, Canada ranked fifth (after the USA, Germany, the U.K. and Japan) in the number of foreign nationals entering the country on a permanent or semi-permanent basis i.e. excluding short-term visitors. On a per capita basis (relative to the size of the population)Canada ranked fourth (after Switzerland,Germany and Norway). Gross migration flows in OECD countries far exceed net gains or losses (Eurostat, 1999). For example, in the case of the United Kingdom in 1998, there were 189,900 in-migrants, and 127,800 out-migrants giving a net gain of 62,100 , the large majority of whom were from Europe and the USA. The rest of the world contributed a net gain of only 13,000 (U.K. International Passenger Survey). By way of comparison, Canada's immigration and emigration, for the period 1991 to 1999, is shown in Table 1.

The table shows that in the course of the decade, until mid-1999, there was a decline in immigration, an increase in emigration and fluctuations in the number of non-permanent residents. The number of immigrants rose again in 1999-2000. The North American Free Trade Agreement facilitated the admission of Canadians to the U.S., in certain professional and managerial occupations, which contributed to the increase in emigration. Statistics Canada also reported a growth in the number of Canadians living abroad temporarily (Statistics Canada, 2000:3; Zhao, 2000). In fact, a notable feature of contemporary international population movement is its temporary nature. Canada as a whole experienced an increase in non-resident travellers by land, sea and air, from 41.66 million in 1995 to 49.1 million in 1999. They were mainly from the United States, but also included an increase from 4.3 million to 4.4 million from other countries (Statistics Canada, Nov. 2000). The majority of these were short-term visitors.

Canada's official immigration programme recognizes three main categories of admission as 'landed immigrants,' i.e. persons admitted with permanent residence status. They are the family (reunion), economic, and humanitarian (refugee)classes. In addition there is a miscellaneous category that includes retirees, "live-incaregivers' and others. The numbers admitted in each of these categories 1997-2000 are shown in Table 2. (The numbers in the economic and refugee classes include dependents admitted with the selected applicants.) Total admissions fell in 1998, recovering in 1999 and 2000, although the business class declined from $9.22 \%$ of the total in 1997 to $6.01 \%$ in 2000 . 
Anthony H. Richmond

Table 1

Mid-year Estimates of International Migration

for Canada: 1991 - 2000

\begin{tabular}{ccrrr}
\hline Period & Immigrants & Emigrants & $\begin{array}{c}\text { Net } \\
\text { Non-Perm* }\end{array}$ & $\begin{array}{c}\text { Net } \\
\text { Migration** }\end{array}$ \\
\hline $\mathbf{1 9 9 1 - 1 9 9 2}$ & 241,810 & 23,071 & $-42,919$ & 175,820 \\
$\mathbf{1 9 9 2 - 1 9 9 3}$ & 265,405 & 21,725 & $-71,185$ & 172,495 \\
$\mathbf{1 9 9 3 - 1 9 9 4}$ & 234,457 & 22,844 & $-22,196$ & 189,417 \\
$\mathbf{1 9 9 4 - 1 9 9 5}$ & 220,123 & 24,431 & $-14,152$ & 181,540 \\
$\mathbf{1 9 9 5 - 1 9 9 6}$ & 216,988 & 24,206 & $-4,192$ & 188,590 \\
$\mathbf{1 9 9 6 - 1 9 9 7}$ & 224,881 & 48,970 & -682 & 175,229 \\
$\mathbf{1 9 9 7 - 1 9 9 8}$ & 194,451 & 58,327 & $-6,171$ & 131,953 \\
$\mathbf{1 9 9 8 - 1 9 9 9}$ & 173,011 & 58,787 & $+11,713$ & 125,937 \\
$\mathbf{1 9 9 9 - 2 0 0 0}$ & 205,468 & 62,131 & $+8,501$ & 151,838 \\
\hline
\end{tabular}

* Increase or decrease in non-permanent residents.

**Calculated as number of immigrants less emigrants, plus or minus net nonpermanent residents.

Source: Statistics Canada. Annual Demographic Statistics, 2000. Table 1.2.

There was a significant shift in the major source countries of immigration to Canada by the end of the twentieth century. In the mid-1990's Hong Kong was the leading country of origin but fell to thirteenth place by 1999, when the People's Republic of China led with 29,095 , or $15.3 \%$, immigrants arriving that year. Altogether, the Asia and Pacific regions supplied half of all immigrants who arrived 1997-1999. Europe (including the United Kingdom) averaged 20\%, while Africa and the Middle East accounted for approximately $17 \%$ of those arriving at the end of the decade (CIC, 2000).

Table 2 does not include people admitted on temporary employment authorizations, student visas, Minister's Permits and others in the non-permanent resident category. In July 1999 there were 247,000 thousand non-permanent residents in Canada, an increasefrom 166,715 enumeratedin the 1996 census. Care must be taken in comparing immigration statistics with temporary employment data, because not all immigrants intend to enter the labour force. In fact the number of persons employed annually, on a temporary basis, substantially exceeded the number of newly arrived immigrants intending to enter the labour force in the late $1990{ }^{\prime} \mathrm{s}^{3}$. In this connection the distinction between 'temporary' and 'permanent' movements becomes blurred (Michalowski, 1993). Figure 1 shows that many of those entering as a 'landed immigrant' were not expected to work. They were the 
Socio-demographic Aspects of Globalization: Canadian Perspectives on Migration

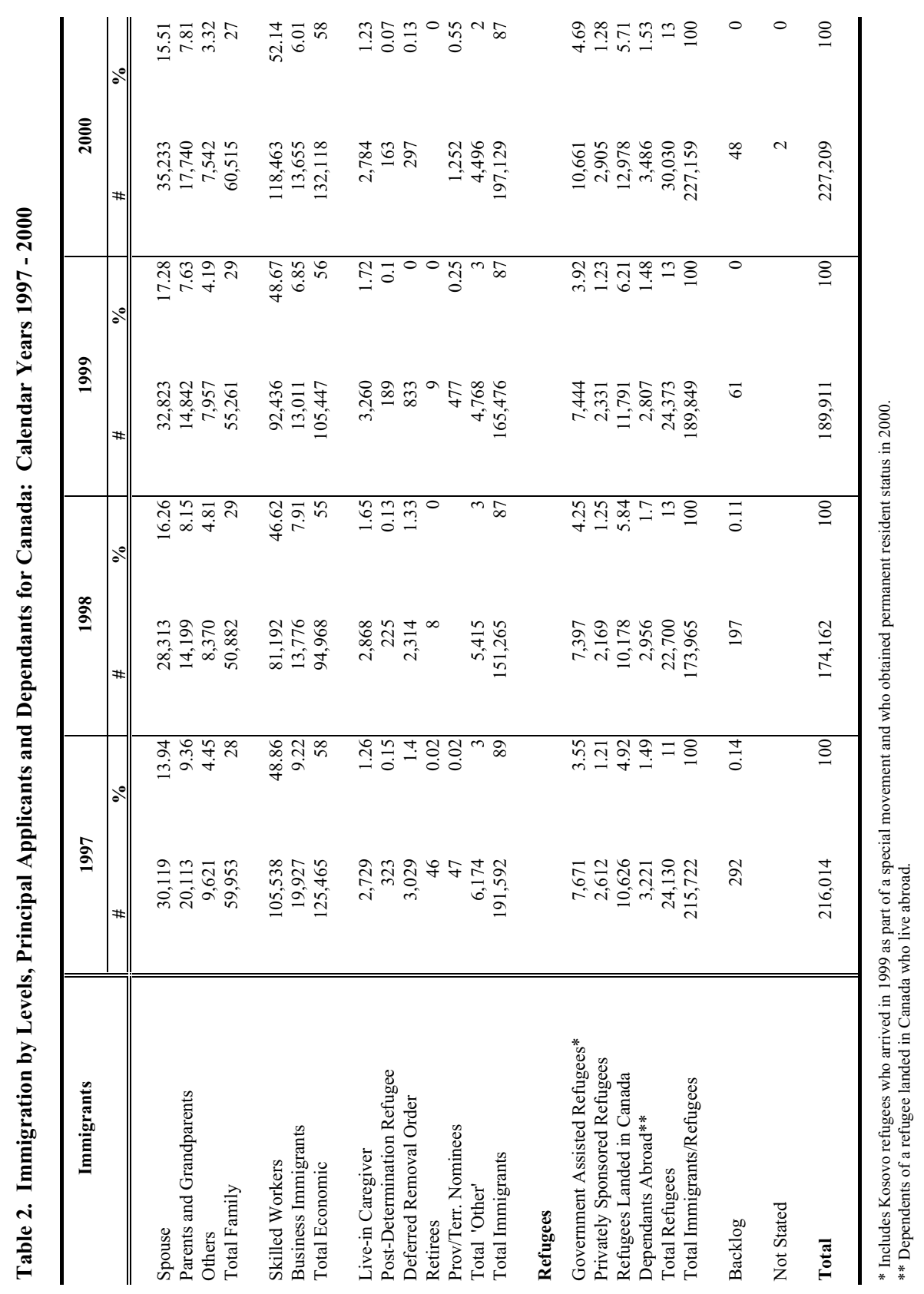


Anthony H. Richmond

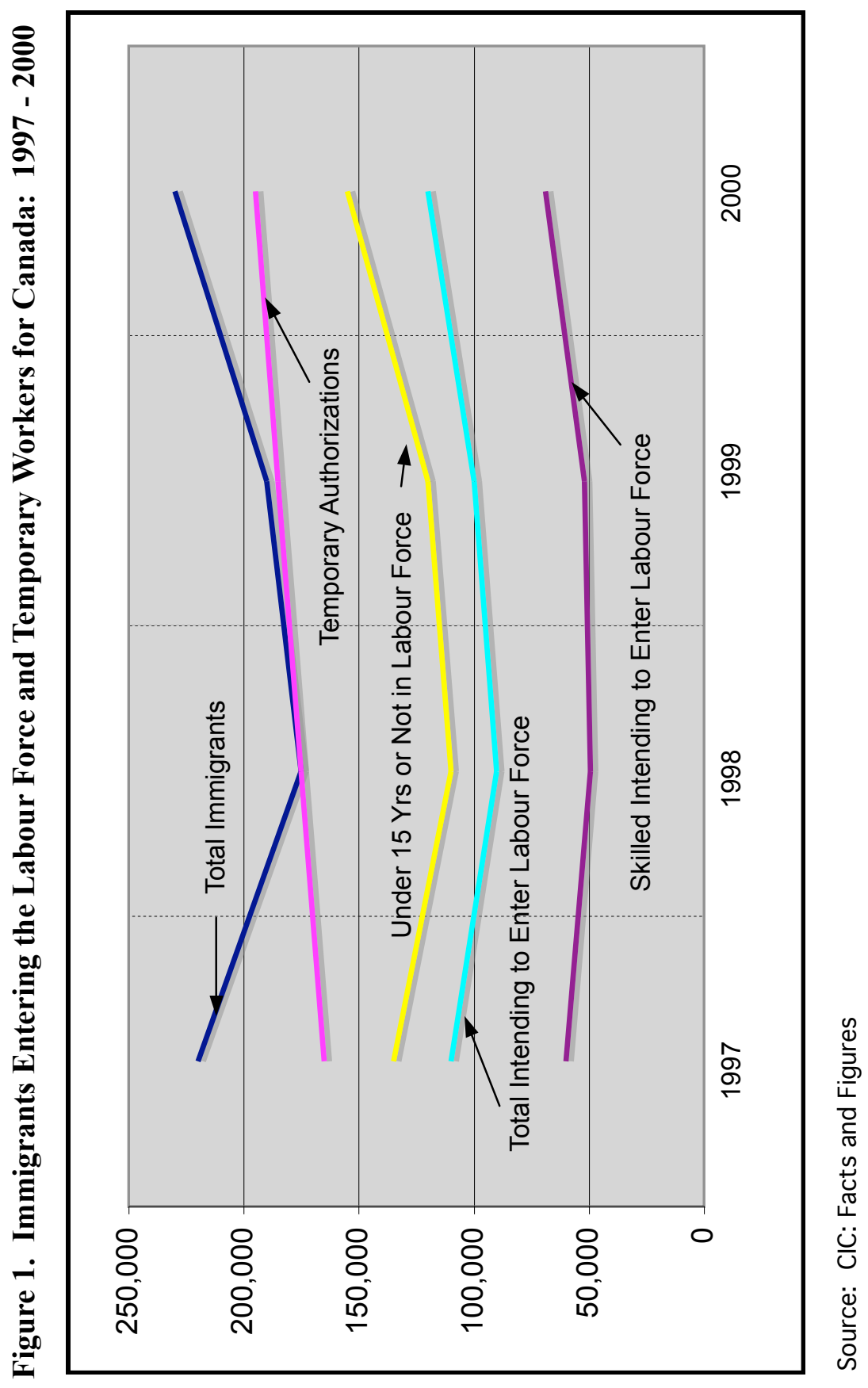


spouses, or children, of the selected immigrant, whether in the family, economic, refugee or other class. Even those landed immigrants expressing an intention to work were not necessarily in the category of skilled workers.

\section{World System}

An explanation of these trends requires a consideration of changes due to globalization. The world is now a total system experiencing radical structural changes, political,economic and social. The impact of these changes is particularly evident in respect of transportation, communication, and the transmission of information and pictorial images. Some experts claimed that we would live in a 'borderless world' (Ohmae, 1990). However, although money, goods and services may move relatively freely, not all people are able to do so. Processes of inclusion and exclusion occur within and between countries and regions. Irrespective of geographic distance, some individuals and collectivities are fully incorporated into the advanced industrial economy of this emerging global system, while others are marginalised. Since the terrorist attacks in the United States, 11 September, 2001, security considerations have further limited freedom of movement between countries.

Although the term 'globalization' entered the vernacularquite recently the processes involved are not new. Economically the 'world capitalist system' can be traced to the sixteenth century (Wallerstein, 1974). Friedman (2000: xvi-xvii) identified an earlier period of globalization, from the 1800's to the late 1920 's, when volumes of international trade, capital movements and the flow of labour across borders was comparable with the current era. The industrial revolution transformed European society in the eighteenth and nineteenth centuries, and the later post-industrial developments, which had a profound effect on global migration, were already evident by the mid-twentieth century. Based on research conducted in the early 1960 's, the term transilient was introduced to describe an internationally mobile labour force (Richmond, 1967:252). It was later suggested:

Individual migrants in post-industrial societies are of the 'transilient' type who do not necessarily settle permanently in any one locality and yet are not 'rootless', alienated or marginal men in the sense in which these terms were understood in the context of traditional or industrial phases of development. Instead they are involved in the worldwide communication network of Verbingdungsnetzschaft that is the characteristic form of social organization in a post-modern society (Richmond, 1969:280).

Although the transilient type of migration was then largely confined to an elite, or 'meritocracy' of professional,managerial and some clerical and technical personnel, it was expected that the absolute numbers would grow as higher education was extended. This refers to what were later called 'proactive' migrants, i.e. those who are able to make rational calculationsconcerning the timing of a move, and relative 
freedom of choice with regard to destination, re-migration or return.

If migration in a post-modern society is placed in this context the concept of 'active mobilization' could be understood to mean a dynamic interaction between motile individuals and collectivities giving rise to information flow and feedback effecting greater control over material and human resources. This is the predominant mode of coaptation of migrants in post-industrial societies. (ibid: 281)

There is a continuum between such types of migration and the more restricted choices made under coercive conditions characteristic of 'reactive' migrants (Richmond, 1988) Governments may issue visas, work permits, temporary residence permits, citizenship certificates, passports and travel documents, in an effort to select, and control the flow of people across borders. However, the growth in tourism, business travel, asylum applications and 'people smuggling,' has made such controls increasingly difficult to enforce. Ease of communication and the compression of time and space have made global migration a new dimension of social stratification. Bauman (1998: 77-102) over-simplified when he distinguished between 'tourists' and 'vagabonds,' but he rightly emphasized the differences in power and status:

What is acclaimedtoday as 'globalization' is geared to the tourists' dreams and desires. Its second effect - a side effect, but an unavoidable one - is the transformation of many others into vagabonds. Vagabonds are refused the right to turn into tourists. They are allowed neither to stay put (there is no site guaranteeing permanence, the end to undesirablemobility) nor search for a better place to be. (Bauman, 1998:93)

By their very nature, clandestine and illegal migrations are hard to quantify. People may enter a country with necessary passports, visas and other documents and then 'overstay' an expiration date. Others may use forged documents to obtain entry by land, sea or air. The most dramatic and widely publicised cases are those where people smuggling is involved (Morrison and Crosland, 2000). It is alleged that there are close links between organized crime syndicates involved in arms and drug smuggling and those responsible for illegal traffic in humans who may be employed, eventually, in prostitution or near 'slave' labour (Robinson, 1999:31521; Ghosh,1998). In the USA one estimate of the number of illegal immigrants entering annually in the mid-1990's was 300,000, the majority being from Mexico or other Latin American countries. Since then, the opening of trade links with China has encouraged trans-Pacific smuggling from mainland China, Korea and elsewhere. Several boat loads of people reached Canada and the United States in 1999 , some of the passengers had genuine asylum claims that were later recognized. The majority of such claims were deemed unjustified and deportation followed, after legal appeals were exhausted, and long delays in processing had occurred. ${ }^{4}$ There were similar problems in Britain that also experienced smuggling in overcrowded trucks travelling though the Channel tunnel. In one case 58 people died in an overcrowded and unventilated vehicle (Richmond, 2000). 
Socio-demographic Aspects of Globalization:

Canadian Perspectives on Migration

\section{Theoretical Perspectives}

The concept of 'time-space distanciation,' introduced by Anthony Giddens, is helpful in understanding the processes involved. ${ }^{5}$ Formally, Giddens defines 'time-space distanciation' as "the stretching of social systems across time-space, on the basis of social and system integration" (Giddens,1984:377). Instantaneous communication means that distances in space and time have become insignificant. Although face-to-face contact is not eliminated, electronic media and satellite links facilitate interaction over long distances. It is interesting to compare the concept of 'time-space distanciation' with a much earlier sociological idea of 'social distance.' The concepts are not synonymous but they are related. The latter was first put forward by Park and Burgess in their studies of migration and ethnic relations in Chicago. They noted the phenomena of 'approach' and 'avoidance' and stated:

If instead of thinking of these two tendencies as unrelated, they are thought of as conflictingresponses to the same situation, where the tendency to approach is modified and complicated by a tendency to withdraw, we get the phenomenon of social distance (Park and Burgess, 1924:440).

There was a vertical as well as a horizontal dimension to 'social distance.' The former involved differential power and status, and the latter the degree of cultural congruity and compatibility. Edward Shils, in his discussion of 'center and periphery' noted that these concepts may be understood as involving 'proximity' and 'distance' in a metaphorical sense. In this context, 'distance" referred to the degree of assimilation into or participation in a collectivity. "Within the limits of membership in the society, which is not simply a matter of territorial location, the distance between peripheries and the center of society can vary considerably" (Shils, 1988: 259). As a consequence of globalization, and the compressionof time and space that it involves, multiple centres generate overlapping peripheries and conflict over boundaries.

Implicit in the idea of social distance are questions of power, social status, communication, mutual tolerance and understanding. As in the case of 'time-space distanciation' there is no necessary coincidence with physical closeness, or geographic proximity, although they could be correlated in some circumstances. Interaction across time and space may break down barriers, and reduce social distance, but it may also generate competition for scarce resources. The consequent 'time-space edges' may be conflicting. There is a close link between the concept of distanciation and that of power. The co-ordination of social systems across time and space involves the resources which, in combination, create structures of domination (Giddens, 1984:258). It is this that gives rise to the process of structuration which, in turn, both constrain and enable human agents to effect change. In this connection information is an important resource that may be stored and retrieved. The accessibility of information is an important component of power relations, and its dissemination by post-modern means of communication has 
fundamentally altered structures of domination. It has also had a profound effect on patterns of internationalmigration. Knowledge of desirable destinationsand 'safe havens,' together with the means of reaching them through regular and/or clandestine channels, are disseminated through networks linked by all available technologies, from radio and television to mobile phones and the internet.

\section{Global Systems of Migrant Incorporation}

Previous studies have identified various types of migration, distinguishing invasion, conquest and colonization from immigration (Fairchild, 1925), as well as different categories based on a combination of ecological, political and psychological factors (Petersen, 1958). More recently it was noted that "migrants are agents of the post-industrial revolution itself providing the society with the knowledge and power to effect the necessary transformation" (Richmond, 1969:280). This gives rise to various modes of incorporation. When the differential distribution of power in the world system is combined with varying degrees of social distance, a fourfold classification is possible as shown in Figure 2. Within the world system, all the types of migrant incorporation indicated in the chart may occur at any time, creating a turbulent climate for change and indeterminate outcomes. Within a given region or country, at a particular time, there will be a greater probability of certain types, although more than one may be present. The balance may shift as power is re-distributed and social distance increases.

When power and status are relatively egalitarian, and resources are accessible, there are two possibilities. These are inclusion (i.e. coaptation) and seclusion (i.e. voluntary isolation). When power and status are unequal a structure of domination is created; the resulting types are subclusion (i.e. subordinated ethclass relations), or various forms of exclusion, (i.e. the coercive separation of peoples ). Within each category there is room for substantial variation in the way migrants (and sedents) are defined legally and perceived socially.

\section{Inclusion (Coaptation)}

Given the distribution of political and economic power in the global capitalist system, those with capital to invest, together with those who manage these resources, are generally welcome in receiving countries. They have few obstacles placed in the way of their temporary or permanent settlement in other countries, either developed or developing, democratic or formerly communist. People with money or skills (i.e. human capital) are able to move comparatively freely

The relationship of proactive professional and business migrants to residents of receiving countries is best described as 'coaptation.' This term is preferred to earlier formulations such as 'assimilation' 'adjustment' or 'adaptation,' because it emphasises the fact that everyone is obliged to come to terms with the reality of multitudinous changes shaping contemporary societies. There is a sense in which 
Figure 2

Global Systems of Migrant Incorporation

\section{POWER/STATUS}

(high)

\section{PROACTIVE}

\begin{tabular}{|c|c|}
\hline INCLUSION & SECLUSION \\
\hline $\begin{array}{l}\text { Investors } \\
\text { Professionals } \\
\text { Skilled (scarce) } \\
\text { Families (of above) } \\
\text { Visa Workers }\end{array}$ & $\begin{array}{l}\text { Wealthy (enclaves) } \\
\text { Retirees } \\
\text { Religious Sects } \\
\text { Irredentist Moves } \\
\text { Nostalgic Returnees }\end{array}$ \\
\hline $\begin{array}{l}\text { "Guest” Workers } \\
\text { Migrant Labourers } \\
\text { Domestic/Service } \\
\text { Illegals } \\
\text { Asylum Applicants }\end{array}$ & $\begin{array}{l}\text { Internal Displaced } \\
\text { Exiles/Deported } \\
\text { Repatriates } \\
\text { Ethnic Cleansed } \\
\text { Refugees 'in orbit' }\end{array}$ \\
\hline SUBCLUSION & EXCLUSION \\
\hline
\end{tabular}


everyone, sedentary populations and movers alike, are 'immigrants' to the twentyfirst century. Post-modern societies are changing so rapidly that sedentary populations may be obliged to adapt just as radically as those who migrate. They have no choice but to respond to the cosmopolitan transformations in their own neighbourhoods. Nowhere are these processes more evident than in Canada, particularly in metropolitan areas, such as Toronto, which receives the largest share of immigrants, as well as visitors and temporary workers.

The increasing use of temporary employment authorizations illustrates the transilient nature of population movements, particularly those involved in the advanced technological sectors. However, seasonal agricultural workers and others employed in domestic service and care-giving also exhibit a pattern of remigration and return. The multi-way movement of professional, managerial and technical workers within the global system has given rise to concerns regarding a 'brain drain' from developing to more advanced industrial countries, and from Canada to the United States. The question is not a new one. Concerns were first expressed in the 1960's and have continued, at intervals, ever since (Thomas, 1961; Beijer, 1969; Pryor, et al. 1990; Zhao, et al. 2000). A recent study of emigration from Canada to the United States concluded:

While losses of highly skilled workers to the United States accelerated during the 1990 's, so did the influx of highly skilled workers into Canada from the rest of the world. This is particularly true of high-technology industries where immigrant workers entering Canada outnumber the outflow to the United states by a wide margin ...... because of the overall greater number of immigrants, there are four times as many university graduates entering Canada from the rest of the world as there are university degree holders of all levels leaving Canada for the United States ( Zhao et al. 2000:1)

However, immigrant professionals frequently have difficulty obtainingaccreditation for their education and experience in other countries. Medical doctors are a particular case in point; although licensing requirements vary between Provinces there is an acute shortage of internships and other opportunities to obtain a license to practise medicine in Canada. Managers, computer scientists and other high technology workers, may have fewer problems in finding appropriate employment because neither licensing requirements, nor trades union and professional association regulations, are an impediment as they often are in more established trades and professions.

The global economy revolves around metropolitan centres that function as nodes of power and influence, linked through communicationnetworks that recognize no boundaries. "Global cities are centers for the servicing and financing of international trade, investment, and headquarter operations" (Sassen, 1998:xxiii) It is not surprising that the large majority of immigrants and temporary migrants are located in metropolitan areas. In Canada in 1996, $85 \%$ of all immigrants lived in metropolitan areas, compared with $57 \%$ of the Canadian born. Ninety-three 
percent of those immigrants who arrived 1991-96 resided in metropolitan areas. Toronto and Vancouverwere the main receivinglocations. Non-permanentresidents are also concentrated in metropolitan areas, two-thirds of them in Toronto.

\section{Subclusion (Ethclasses)}

There is potential conflict of interest between people living and working in the 'city-states' ( whether rich or poor) and residents of rural areas and small towns, including those dependent on declining primary industries such as fishing. The vast 'suburban metroplexes' of the United States forge their own external trade policies which tie them to Canada, Mexico and other similar centres around the world, in an inter-linked global economy. As well as legitimate trade, there is a global criminal economy that includes drugs, arms and the smuggling of people. (Kaplan, 2000; Castells, 1998; Robinson,1999.)

A study of migration systems in Pacific Asia, including Hong Kong, demonstrates the link between current trends in international migration and globalization. Employment patterns in the electronics industry indicated links between a global city and its hinterland. It was concluded that "High levels of low-wage and significant levels of highly-skilled migration will remain a prerequisite for success of the dragon economies in the foreseeable future if they are to maintain their powerful global positions" ( Findlay, 2001:149)

Migrants who are low in power interact with receiving societies in subordinate status positions, undertaking work that is poorly paid and largely rejected by the resident population. I use the term "subclusion" synonymously with the term 'undercasting' (Hoffman-Nowotny, 1981:74-5). That is to say, persons denied full citizenship rights and permanent residence in the place to which they have moved, together with those who lack skills, i.e. human capital and/or who experience discrimination. The systems of ethnic stratification in contemporarypost-industrial societies differ from those in earlier stages of industrial capitalism in that the formations are global. Whether as a consequence of the mobility of capital (and capitalists) or the demand for cheap labour for agriculturaland service occupations, there are no effective national boundaries. Entrepreneurs with money to invest have little difficulty obtaining residence permits, immigrant status, or even citizenship of the countries they wish to operate in (Richmond, 1994) ${ }^{8}$. This is not the case for those who bring only their labour, or who are deemed alien in language or culture. In Canada, as in other countries, 'visible minorities' have lower incomes and experience a much higher level of poverty than others. A recent study in Toronto concluded:

... combining all non-Europeangroups, the family poverty rate is 34.3 per cent, more than twice the figure for Europeans and Canadians. Non-European families make up 36.9 percent of all families, but account for 58.9 percent of poor families.... In each of the six categories of families, Torontonians of European origin have the highest median incomes. (Ornstein 2000, p 97) 
The situation is currently aggravated by the structural changes that are taking place in the global capitalist system as a result of technological innovation, international competition, the availability of cheap labour in developing countries, and economic recession. Processes of inclusion and exclusion occur within, as well as between, countries. The dismantling of the 'welfare state,' privatizing of many services, the removal of established 'safety-nets' and the substitution of 'workfare' are all symptomatic of a shifting balance of power in the global system. The consequent vogue for 'downsizing,' and the de-industrialization in some advanced societies, has ironic ethnic consequences. It is precisely those who have enjoyed the greatest privilege in the past, namely the unionized (mainly 'white') blue collar (and some clerical and service) workers, who are being made redundant. There is a consequent reaction against employment equity and affirmative action programmes, which previously favoured women and visible minorities. Young white males with little education, whether immigrant or native-born, may also see themselves as victims of systemic discrimination. When unemployment is high the result is alienation, and increasing support for a right wing political agenda and neo-fascist movements. Racial and ethnic prejudices are inflamed. A shift toward coercive exclusionary measures, or what has been called 'global apartheid' then occurs (Richmond, 1994; 2001). (The term 'apartheid' is appropriate when passports, visas, work permits and other documents are used to determine residence rights, access to health and education services and impose a liability for return to 'homelands.' These rights, privileges and penalties may be differentially accessible according to ethnic, racial, religious or national criteria.)

\section{Exclusion (Apartheid)}

Literally, apartheid simply means separateness. In practice, as politically institutionalized in South Africa, it was a system of oppression by a minority of mainly European (British and Dutch) origin against the majority of African, Asian and mixed ethnic origins. By denying the vote, allocating people to Reserves or 'Homelands,' using 'pass laws,' controlling education, imposing residential segregation, restricting access to better paid jobs, outlawing mixed marriages, and using military means, exile and imprisonment to suppress dissent, the government exercised totalitarian control over the lives of the majority. The South African example is only one extreme version of a process that can be seen at work in other parts of the world, where a combination of inequality and social distance combine to create forms of coercive separatism. Censorship and other barriers to communication may be instituted in order to reduce, or eliminate, outside influence. Schools and universities may become instruments of linguistic, religious and political indoctrination. Other examples include the Chinese treatment of Tibetans, and other religious minorities, as well as various ethnic conflictsin Asia, Africa, the Middle East and the former Yugoslavia.

In its most extreme form exclusion leads to genocide, i.e. the systematic large scale extermination of a racial or ethno-religious group perceived as threatening. Since the atrocities in the former Yugoslavia the term 'ethnic cleansing' has been used to describe such attempts. Other less extreme manifestations lead to the partition of 
territory, the expulsion, exile or deportation of minorities, and/or the repatriation of those previously allowed refuge or asylum. Struggles for power between rival ethnic groups have become militarized in the post- cold- war era, as formerly totalitarian regimes lose their dictatorial control and monopoly over weapons. Terrorism is one result. However, care must be taken in using the term 'terrorism.' As Aiken $(2000 ; 2001)$ has noted, exaggerated concern with 'national security' has led to governments to 'manufacture terrorists' by laws and practices which potentially threaten fundamental human rights. Victims of political turmoil may flee the country but they do not necessarily find a warm welcome elsewhere. While states reserve the right to control movement across borders and endeavour to prevent 'illegal' immigration, mass migration occurs with or without legal sanction. People move from less developed to developed countries, and regions, to perform menial or dirty work, provide domestic services, or to supply field labour for agro-business. This category also includes some reactive migrants who succeed in moving to a country prepared to consider asylum applicants, although not necessarily award them Convention refugee status.

The victims of political and ethnic power struggles account for large-scale movements of refugees that have occurred in eastern and central Europe, Africa, Asia and Latin America. Developed countries in western Europe, North America and Australasia are reluctant to give asylum to all those who flee persecution, or seek to escape the economic and environmental disasters that occur in the wake of such conflicts. Many internally displaced persons, as well as so-called 'economic migrants' (together with those who cannot prove that they personally have been, or could be, victims of persecution), are being denied refugee status, by using a strict and narrow interpretation of the Geneva Convention criteria ${ }^{9}$

Various practises are used by wealthier countries to manage and control population movements. They involve classifying people accordingto their perceived eligibility to enter, or remain in, a particular territory. As in South Africa, the instruments for the enforcement of global apartheid are interdiction, passports, visas, residence permits, work permits, denial of citizenship rights (including access to education, government funded health and welfare services etc.). The forcible repatriation of refugees to "Homelands", or so-called 'safe third countries,' is now standard practise, together with the deportation of 'illegal' immigrants (Roberts, 1998). These forms of state control of immigration are seen as a legitimate response to the de-stabilizing effects of large-scale migration. They are discriminatory by 'race' because the majority of refugees and asylum applicants come from, and are obliged to remain in, Third World countries.

Trends in the number and distribution of refugees and asylum seekers by world regions 1998-2000 are shown in Table 3. Between 1997 and 1998 the number of asylum seekers in Europe rose from 267,400 to 576,900; the numbers fell slightly in 1999 and in 2000 (to 332,900), largely as a consequence of the interdiction and deterrent efforts made by the European Union. The latter were so drastic that the UNHCR Policy Unit expressed concern that it was becoming almost impossible for genuine asylum seekers to obtain legal entrance to a EU country, forcing people to adopt clandestine methods and to fall victim to unscrupulous traffickers. The 
Anthony H. Richmond

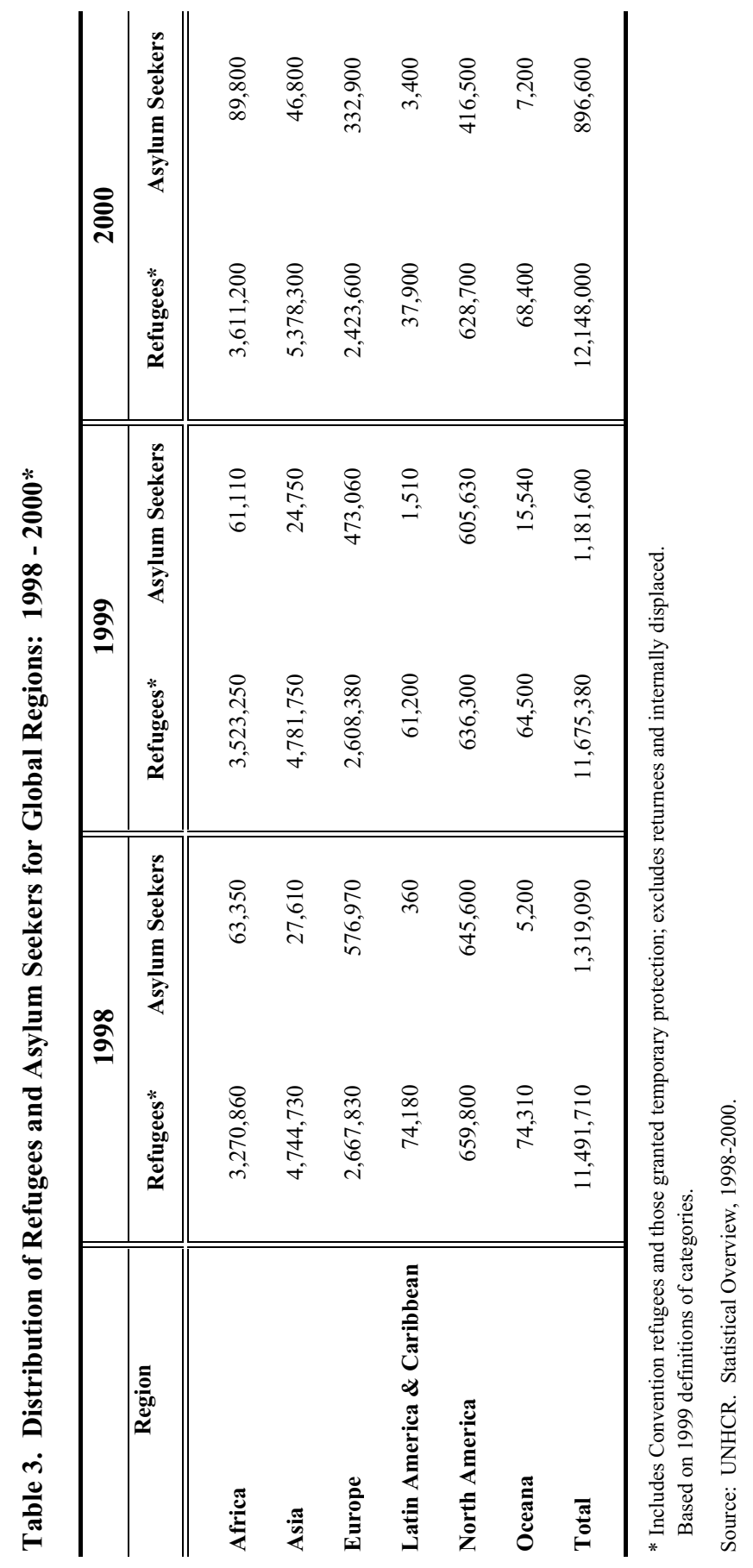


authors of this report noted that there was emphasis on closing down criminal activities without ensuring that there were alternative means of migration for those who had a genuine fear of persecution.

Refugees are now forced to use illegal means if they want to access Europe at all. The direction of current policy risks not so much the problem of trafficking but rather the ending of the right to asylum in Europe, one of the most fundamental of human rights (Morrison and Crosland, 2000).

Governments now use advanced technologies to maintain data banks on suspected terrorists, known criminals, asylum applicants and alleged 'illegal' immigrants. They institute 'early warning systems' against mass migration, train airline officials in the checking of documents to facilitate interdiction, and enforce the 'non-exodus' of unwanted populations. ${ }^{10}$ Electronic fences replace barbed wire and brick walls, while police and soldiers continue to back-up immigration officials at borders, and gunboats support the coast guards as they herd people into internment camps, pending repatriation.

When all those of concern to the UNHCR are considered, including the internally displaced and returnees, Asian countries carry the heaviest burden, followed closely by Africa and the Middle East (seeFigure 3). Even before the bombing in 2001, Afghanistan was the single largest source of refugees under UNHCR auspices, the majority located in camps in Pakistan and Iran (UNHCR 2000). There were an estimated 12.15 million 'Convention' refugees, and many externally and internally displaced persons in the year 2000. Altogether, the UNHCR reported 22.26 million persons of concern to that agency in the year $2000^{11}$. At the same time there is growing fear, in Europe and North America, of large scale economic migration from developing counties, induced by poverty, and a sense of relative deprivation compared with the evident affluence of the West.

Attempts to limit the flow of refugees and asylum applicants are part of a growing nostalgia for a less complicated world, in which people felt secure in homogeneous communities, where neighbours shared 'traditional' values. It is also a reaction to the insecurity felt by many faced with a rapidly changing global society. This is evident in the growth of racism, xenophobia, religious and ethnic conflict in various countries, including those that have traditionally been receptive to both political and economic migrants. Politically, it is expressed in the coordinated efforts of countries in Western Europe, North America and Australia to deter asylum applications and limit mass migration to these regions. There is a growing fear in Europe concerning the possibility of mass migration from east to west, and an equal concern about the potential flow from south to north, including those from Mahgreb territories of the southern Mediterranean and Africa, to Spain, Portugal, France and Germany (Glenn, 1992; Rogers \& Copeland, 1993). 
Figure 3

Refugees and Others of Concern to UNHCR: 2000

Note: $N=21,126,010$; Includes returnees and internally displaced.

Latin America \& Caribbean $2.7 \%$

North America 4.9\%

Oceania $0.4 \%$

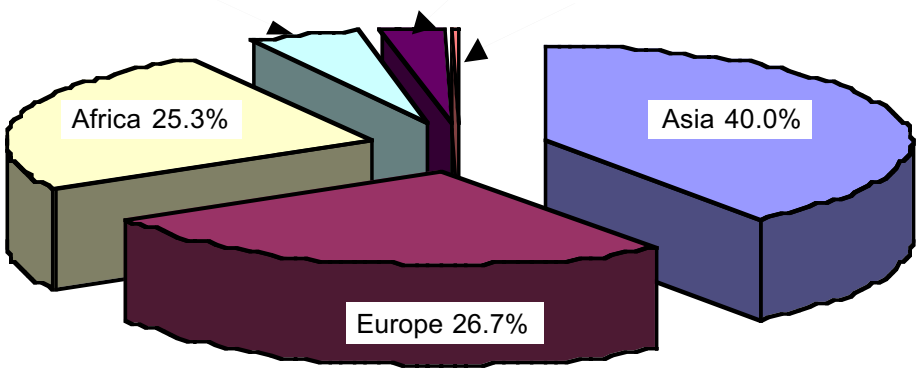

Source: UNHCR. Statistical Overview. April, 2001.

Recently, new immigration legislation was introduced in several countries, including Britain, Germany, the USA and Canada, which severely restricts the number of successful asylum applicants and aims to deter illegal entrants and 'smuggling' (Richmond, 1994; 2000). ${ }^{12}$ Various countries have introduced legislation that requires refugees to be fingerprinted, restricts access by asylum applicants to public housing, permits deportation where an asylum claim has been refused, and requires air lines, or other carriers, to ensure that travellers hold a visa to enter, or even to pass through one country en route to another. Potential refugees must have their asylum claims processed in the first 'safe country' they land in. This gives rise to the phenomenon of 'refugees in orbit' when no country wishes to accept them. Canada's interpretation of the UN Convention definition of a refugee has been more generous than that of some other countries. ${ }^{14}$ In 1999 , the overall acceptance rate was $58 \%$ of those who reached Canada and who applied for asylum. When asylum applications that are withdrawn, or abandoned, are taken into account the average acceptance rate is reduced to $46 \%$ of all claims initially filed. In the year 2000 the proportion was $48 \%$. The highest approval rate was for those from Afghanistan (89\%). 
Socio-demographic Aspects of Globalization:

Canadian Perspectives on Migration

\section{Seclusion (Separatism)}

The fourth category of migration, both international and internal, arises when power and status are relatively high and people wish to minimise the consequences of contemporary social change. This may be achieved by what Giddens calls 'disengagement from the hostile other" (Giddens, in Beck et.al., 1994:105). Its symptoms are evident in the increasing number of people, particularly the wealthy who live in walled communities, surrounded by security guards. Retirement communities exhibit similar tendency toward self-segregation. Religious sects who set up communes are an example of a withdrawal from the every-day world .The spate of millennial related mass suicides may be understood as the ultimate expression of this propensity to escape contemporary realities and seek seclusion, through the migration of the soul to another level or planet. (Suicide bombers may be similar motivated).

Returnees who have a nostalgic desire to rediscover their roots, are also in this category. Others include those who move as a result of irredentist efforts to reunite particular ethnic communities that have been separated by arbitrary political boundaries. Other examples include flight to the suburbs of formerly dominant ethnic groups when faced with the increasing racial and ethnic diversification of global cities, and the proactive emigration of wealthy elites in search of tax havens, or when faced with a major shift in power relations, such as occurred in South Africa when apartheid came to an end. Although it is not possible to quantify the phenomenon, 'seclusion' and 'exclusion' may be understood as complementary to each other.

\section{Conclusions}

In a study of immigration, and what he called the 'New World Worker,' economist Nigel Harris argued the case for removing all barriers to immigration in the interests of a global free market economy. He foresaw a situation in which, as transport grows faster, people will live in one place and work in another, as indeed city commuters do already. He stated "At an extreme, the entire labour force might live outside the country" (Harris, 1995:225). He pointed out that, already there are software programmers living in Bombay but, technically, working in New York. If such a situation were to become the norm it would, indeed, be the logical outcome of 'time-space distanciation' taken to its ultimate conclusion. Such a development is extremely unlikely to become universal. Distance education is one sphere where it is feasible, but other services, such as health care, domestic help, and the cleaning and maintenance of buildings and public utilities, all require workers to be present in a particular location. There are physical limitations to the impact of time-space distanciation on social systems. Food can be imported and goods manufactured abroad. Financial transactions, computer programming, architectural and engineering designing, data processing and TV entertainment can all be provided from a distance. In an emergency, expert advice may be transmitted to a surgeon, or other specialist, from a distance, but someone must carry out the 
operation on the spot. If you want your haircut, your floors swept or your appendix taken out, you will need someone close by who will do it, although remote controlled robotics are possible. However, modern communications technology will not eliminate the phenomenon of migration, although it will undoubtedly revolutionize it in many ways.

Most post-industrial societies currently have low birth rates and an ageing population. This is particularly true of Britain and Europe and, to a lesser extent, Canada. It has been suggested that immigration may be the answer to a shrinking labour force and a growing burden of old-age dependency. It has been calculated that, in order to maintain a constant old-age dependency ratio in the European Union, between now and year 2030, would require an average annual net migration close to 13 million per annum. Given the extent of emigration, gross migration rates would have to be even higher (Visco, 2000; UN Population Division, 2000). As immigrants age at the same rate as the rest of the population, the longer term consequences of low birth rates could be reversed by allowing only the immigration of orphans under the age of five! Politically and socially such a scheme is impractical, even if humanitarian considerations were to encourage the admission of children from refugee camps, or others in need. In the case of Australia it has been shown that "levels of annual net migration above 80,000 become increasingly ineffective and inefficient in the retarding of ageing" (McDonald and Kippen, 2001:174).

From a global perspective, and in view of the environmental consequences, it is necessary to consider whether any increase in population in the wealthiestcountries and continents is desirable, unless drastic measures are taken to reduce pollution and global warming (Mungall and McLaren,1990). The world's population is expected to grow from six billion to nine billion by the year 2050. Most of this growth will be in Africa and Asia where, even assuming improved nutrition and health, resource consumption and consequent pollution and environmental damage will be less per capita than in Europe, or North America. Nevertheless, the pressure to migrate from poorer to richer areas is likely to persist, as is urbanization within the developing world. There is an established link between environmental scarcity and violent conflict in developing countries which can only induce further reactive migration (Homer-Dixon, 1999).

Globalization, whether driven by market forces or technological innovation, will not necessarily eradicatepoverty, reduce inequalityor prevent civil wars of the kind that have devastated Afghanistan, Cambodia, Rwanda, Zaire, Yugoslavia and Indonesia (to name a few). We can be sure that both proactive and reactive migration will continue, and remain a source of concern to policy makers in the $21^{\text {st }}$ century. The security issues that have been magnified by terrorist threats since 11, September, 2001 will lead to further differentiation between those who are qualified and fully documented, and those who are not. The former will be free to cross state borders, while the latter will be denied visas, excluded, interdicted, held in detention or deported. Ideally, cross border population movements should be facilitated through bi-lateral and multi-lateral agreements that ensure reciprocity in all dimensions of human rights. The rights and claims of foreigners, residents and aliens, as well as their conditions of entry into liberal democratic countries (to 
visit, work, or study) need to be protected.social entitlements, benefits, and claims similar to the rights of those with permanent residency or full citizenship, need to be recognised (Benhabib, 1999; Bohning, 1991; 1999; ILO, 1997). As a first step, the ratification of the I. L. O. draft "Convention on the Protection of the Rights of all Migrant Workers and Members of their Families" by Canada, the US and other industrialized countries is important. The positive benefits of migration need to be recognised. Rather than imposing restrictions that encourage clandestine movements, governments should facilitate temporary and permanent cross border movements through bi-lateral and multi-lateral agreements. This would go a long way toward removing some of the abuses currently associated with the employment of temporary workers (Commission on Global Governance, 1999:207).

Hopefully, current concerns with regard to human security, and terrorist threats, will not lead to such an over-reaction that draconian measures will be put in place, undermining a commitment to human rights and freedom. Globalization is here to stay as is international migration. Canada could set an example of how to respond to the inevitable stresses and strains. However, in a world fearful of terrorist activity, security considerations are likely to supersede concern for the rights of migrant workers, or refugees.

\section{End Notes:}

1. The internationally accepted definition of immigration and emigration, for demographic purposes, is any person entering or leaving a country with the intention of remaining for one year or more. Care must be taken in comparing Canada's statistics of immigration with those of other countries. Canada's official immigration numbers include only those admitted as 'landed immigrants' or 'permanent residents.' Because they do not need to report their move, CIC does not include Canadian citizens leaving the country for a year or more, or those returning from the US or other countries. Revenue Canada reported an increase in the number of tax-filers who ceased to reside in Canada from 15,360 in 1991 to 28,870 in 1997 (United Nations, 1980; Michalowski, 1993; Zhao,2000).

2. Statistics Canada defines a 'non-permanent resident' as anyone granted the right to live in Canada temporarily. This includes refugee claimants, those with temporary work permits, student authorizations and Minister's Permits, together with their dependents. The census of 1991 enumerated 223,410 non-permanent residents, and 166,715 in 1996 . The number of non-permanent residents enumerated in the 2001 census is not known at the time of writing. The best estimate is approximately 290,000 .

3. Originally, the spouse of a person issued a temporary employment authorization was not permitted to work in Canada. When, in 1998, the government decided to encourage the entry of information technology experts and soft-ware developers, this rule was relaxed (CIC Performance Report, March, 1999, p.9). 
4. Under the terms of Canada's Immigration Act there are several types of removal order. In 1998 there were 2,365 departure orders, 2,956 deemed deportations, 1,743 deportations and 898 exclusion orders. NB If a person is issued a departure order but does not leave Canada within 30 days and does not confirm the departure with CIC, the departure order automatically becomes a 'deemed deportation' order. The number of people removed from Canada in 1998 was 8,012 of whom $62 \%$ were failed refugee claimants, and $22 \%$ were criminals ( CIC EnforcementFact Sheet, April 1999). By October 2000 there were still 91Chinese detainees in British Columbia some of whom were on hunger strike. It was reported that 40 or more were about to be deported.

5. Castells (1996) prefers the term 'time space compression.' He notes the increasing interdependence of the labour force on a global scale and associated cross-border networks

6. Attitudes and values may be internalized as a result of the degree of timespace distanciation actually experienced. Hypothetically, one would expect a small negative correlation between high levels of distanciation and greater social distance i.e. closer communication would lead to a reduction in prejudice. However, there would be many exceptions to this, depending upon intervening variables, such as perceived economic competition.

7. Since its establishment the Canadian Immigrant Investment Program generated over \$4 billion in investment. Commencing April, 1999 a redesigned version required applicants to have a net worth of at least $\$ 800,000$ and to invest a minimum of $\$ 400,000$ Between four and six thousand investors entered Canada 1996-98. (CIC Performance Report, March 1999).

8. Laxer (1995:299) notes that "While millions of desperate migrants are turned back at borders and many others endure exploitation and abuse as illegal aliens, rich foreigners have recently been give special treatment." He cites Canada, the USA and Australia, who admit entrepreneurs for a price ranging up from a quarter of million dollars.

9. The 1951 UN Convention on Refugees (as amended in New York, 1967) was a product of the 'Cold War,' and is inadequate for today's political and economic crises. The Convention, as interpreted by Canada and other countries, places the onus on the individual seeking asylum to prove that they would be personally at risk, if returned to their former country. Only a small proportion of all asylum seekers, globally, are successful in their claims, and there is enormous variation from one receiving country to another in acceptance rates. (Hathaway, 1996). 
Socio-demographic Aspects of Globalization:

Canadian Perspectives on Migration

10. In the Canadian case, the number of interceptions of improperly documented passengers increased from approximately 3,200 in 1993 to over 6,000 in 1998. At the same time the number actually reaching Canada's ports of entry declined 6\% between 1997 and 1998.

11. An additional 3.8 million Palestinians were covered by a separate mandate of the U.N. Relief and Works Agency.

12. Canada introduced Bill C31 which died when an election was called in October,2000. A revised version (Bill C11) was subsequently passed in the House of Commons. At the time of writing it was before the Senate. Following the terrorist attacks on the USA, it is expected that the new Canadian immigration law will strengthen the powers of immigration officers to refuse entry to Canada on grounds of criminality, security risk, or forged or inadequate identity documents.

It will impose higher maximum penalties for human smuggling, and place the responsibility on airlines to identify and inform CIC concerning passengers who may be inadmissible to Canada. New identity cards will be issued to landed immigrants. It remains to be seen what further steps will be taken to protect the North American 'perimeter' and facilitate traffic across the Canada/USA border.

13. For a detailed account of recent practice and suggested reforms of refugee law see Hathaway and Dent (1995) and Hathaway (1996).

14. The Canadian acceptance of Convention refugees compares with a rate of $22 \%$ in Britain, although the latter country gave 'exceptional leave to remain' to a further $41 \%$ in 1999 . (Richmond, 2000:36)

\section{References :}

Aiken, Sharryn J .2001. "Manufacturing terrorists: Refugees, national security and Canadian law," Part 2. Refuge 19.4: 116-133.

Aiken, Sharryn J. 2000. "Manufacturing terrorists: Refugees, national security and Canadian law," Part 1. Refuge 19.3: 54-73.

Bauman, Zygmont. 1998. Globalisation: The Human Consequences. Cambridge: Polity Press.

Beck, U., A. Giddens, \& S. Lash. 1994. Reflexive Modernization: Politics, Tradition and Aesthetics in the Modern Social Order. Cambridge: Polity Press.

Beijer, G. 1969. "Modern patterns of international migratory movements," in J. Jackson (ed.) Migration. Cambridge: Cambridge University Press. Pp. 11-59. 
Anthony H. Richmond

Benhabib, Seyla. 1999. "Citizens, resident aliens in a changing world: Political membership in a global era," Social Research, 66.3: 709-744.

Bohning, R. 1991. "The I.L.O. and the new UN convention on migrant workers: the past and the future," International Migration Review. 24.4: 698-709.

Bohning, R. 1999. "Protection, International Norms and the Migrant Workers Standards." Paper presented at I.L.O. Asian-Pacific Regional Symposium.

Castells, Manuel. 1996. The Rise of the Network Society. Oxford: Blackwell.

CIC. 1999. Performance report for the period ending March 31, 1999. Ottawa: Citizenship and Immigration Canada.

CIC. 1999. Enforcement Fact Sheet :Removals, Ottawa: Citizenship and Immigration Canada.

CIC. 2000. Facts and Figures 1999: Immigration Overview, Ottawa: Citizenship and Immigration Canada.

Commission on Global Governance .1995. Our Global Neighbourhood. Oxford: Oxford University Press.

Eurostat. 2000. Demographic Statistics, Yearbook 2000.

Fairchild, H.P. 1925. Immigration: A World Movement and its American Significance. New York: Macmillan.

Findlay, Allan M. 2001. "International Migration and Globalization: An Investigation of Migration Press systems in Pacific Asia with particular reference to Hong Kong," in M. A. B. Siddiquue (ed.) International Migration into the $21^{\text {st }}$ Century: Essays in honour of Reginald Appleyard, Cheltenham U.K. and Northampton, M.A. U.S.A.: Edward Elgar. Pp. 126-177.

Friedman T.L. 2000 .The Lexus and the Olive Tree. New York: Anchor Books.

Ghosh, Bimal.1998. Huddled Masses and Uncertain Shores: Insights into Irregular Migration. The Hague: Martinus Nijhof.

Giddens, A. 1984. The Constitution of Society: Outline of the Theory of Structuration. Cambridge: Polity Press.

Glenn, H.P.1992. Strangers at the Gate: Refugees, illegal entrants and procedural justice. Cowansfield, P.Q. Les Editions Yvon Blais 
Socio-demographic Aspects of Globalization:

Canadian Perspectives on Migration

Harris, Nigel. 1995. The New Untouchables: Immigration and the New World Worker. London: I.B. Tauris.

Hathaway „J .C.. 1996. "Toward the reformulation of refugee law," Refuge, 151: $1-5$.

Hathaway, J.C. and J.A. Dent. 1995. Refugee Rights: Report on a Comparative Survey. Toronto: York Lanes Press.

Hoffman-Nowotny, H-J. 1981.”A Sociological approach Toward a General Theory of Migration," in M. M. Kritz, C. B. Keely, and S. M. Tomasi, Global Trends in Migration: Theory and Research on International Population Movements, New York: Center for Migration Studies.

Homer-Dixon, T. F. 1999. Environment, Scarcity and Violence. Princeton N. J.: Princeton University Press

I.L.O. 1997. Tripartite Meeting of Experts on the Future of I.L.O. Activities in the Field of Migration. Geneva: International labour Office.

Kaplan, Robert D. 2001. The Coming Anarchy: Shattering the Dreams of the Post Cold War. New York: Vintage Books.

Laxer, G. 1995. "Social solidarity, democracy and global capitalism," Canadian Review of Sociology and Anthropology 32.3: 287-314.

McDonald, Peter and R. Kippen. 2001. "The Impact of Immigration on the ageing of Australia's Population," in M.A.B. Siddique (ed.) International Migration into the $21^{\text {st }}$ Century: Essays in honour of Reginald Appleyard. Cheltenham, U.K. and Northampton, M.A. USA: Edward Elgar.

Michalowski, M. 1993. "A redefining the concept of immigration to Canada," Canadian Studies in Population 20.1:59-84

Morrison, John and B. Crosland. 2000. The Trafficking and Smuggling of Refugees : The End Game in European Asylum Policy, Geneva: UNHCR Policy Unit.

Mungall, C. and D .J. McLaren. 1990. Planet under Stress: The Challenge of Global Change, Toronto: Oxford University Press.

Ohmae, K. 1990. The Borderless World: Power and Strategy in the Interlinked Economy. New York: Harper Business.

Ornstein, Michael. 2000. Ethno-Racial Inequality in the City of Toronto: An Analysis of 1996 Census Data, Toronto: York University, Institute for Social Research. 
Anthony H. Richmond

Park, R. E. and N. Burgess. 1924. Introduction to the Science of Sociology. Chicago: University of Chicago Press.

Petersen, William. 1958. "A general typology of migration," American Sociological Review, 23.3: 256-65.

Pryor, Edward T., M. V. George et. al. 1990. Migration Between the United States and Canada. Ottawa: Statistics Canada (Cat. No. 91-530E).

Richmond, Anthony H. 2001. "Global apartheid: A postscript," Refuge 19.4: 8-13.

Richmond, Anthony H. 2000. "Refugees and asylum seekers in Britain: U.K. Immigration and Asylum Act, 1999," Refuge 19.1: 35-4.

Richmond, Anthony H. 1994. Global Apartheid: Refugees, Racism and the New World Order. Toronto: Oxford University Press Canada.

Richmond, Anthony H. 1988. 'Sociological theories of international migration: The case of refugees," Current Sociology, 36. 2., Summer, 1988. Pp. 7-25.

Richmond, Anthony H. 1969. "Sociology of migration in industrial and postindustrial societies," in J. A. Jackson (ed). Migration, Cambridge: Cambridge University Press. Pp. 238-281.

Richmond, Anthony H. 1967. Post-war Immigrants in Canada. Toronto: University of Toronto Press.

Roberts, Adam. 1998. "More refugees, less asylum: A regime in transformation," Journal of Refugee Studies. 11.4.: 375-395

Robinson, Jeffrey. 1999. The Merger: How Organized Crime is Taking Over Canada and the World. Toronto: McClelland and Stewart.

Rogers, Rosemary and E. Copeland. 1993. Forced Migration: Policy Issues in the Post-Cold-War World, Medford Mass.: Fletcher School, Tufts University.

Salt, John. 2001. "The Business of International Migration," in M. A. B. Siddique. Cheltenham, U. K., Northampton, M.A. and Edward Elgar (Eds.) International Migration into the 21 $1^{\text {st }}$ Century: Essays in Honour of Reginald Apppleyard. 2001: 86-108.

Sassen, Sakia .1998. Globalization and its Discontents. New York: The New Press 
Socio-demographic Aspects of Globalization:

Canadian Perspectives on Migration

Shils, Edward. 1988 " Center and Periphery: An Idea and its Career, 19351987," in L. Greenfeld and M. Martin, (Eds.) Center: Ideas and Institutions. Chicago: University of Chicago Press. Pp. 250-282.

Statistics Canada, 2001. Annual Demographic Statistics, 2000, Ottawa: Statistics Canada.

Statistics Canada. November,2000. "Non Resident Travellers Entering Canada," CANSIM .

Thomas, B. 1961. "Trends in the international migration of skilled manpower," Migration, 1.3: 5-10.

U.K. 2001. International Passenger Survey, 2000. London: Government Statistical Office.

U.N. Population Division. 2000. Replacement Migration, Geneva : UN Population Division.

UNHCR. 2000. Refugees and Others of Concern to the UNHCR: 1999 Statistical Overview. Geneva: United Nations High Commission for Refugees.

UNHCR .2000. UNHCR Global Report. Geneva: United Nations High Commission for Refugees.

Visco, Ignazio. 2000. "Immigration ,Development and the Labour Market," paper presented at a conference Migration Scenarios for the $21^{\text {st }}$ Century, Rome: OECD.

Wallerstain, I. 1974. The Modern World System. New York: Academic Press.

Zhao, J., Drew, D. and Murray T. S. 2000. "Brain Drain and Brain Gain: The Migration of Knowledge Workers from and to Canada," Education Quarterly Review, 6.3.

Received December 2000; Revised November 2001 
Anthony H. Richmond

11. The internationally accepted definition of immigration and emigration, for demographic purposes, is any person entering or leaving a country with the intention of remaining for one year or more. Care must be taken in comparing Canada $=\mathrm{s}$ statistics of immigration with those of other countries. Canada $=\mathrm{s}$ official immigration numbers include only those admitted as Alanded immigrants@or Apermanent residents@.Because they do not need to report their move, CIC does not include Canadian citizens leaving the country for a year or more, or those returning from the US or other countries. Revenue Canada reported an increase in the number of tax-filers who ceased to reside in Canada from 15,360 in 1991 to 28,870 in 1997 ( United Nations,1980; Michalowski,1993; Zhao,2000).

2.Statistics Canada defines a Anon-permanent resident@ as anyone granted the right to live in Canada temporarily. This includes refugee claimants, those with temporary work permits, student authorizations and Minister=s Permits, together with their 
Socio-demographic Aspects of Globalization:

Canadian Perspectives on Migration

dependents. The census of 1991 enumerated 223,410 non-

permanent residents, and 166,715 in 1996 . The number of non-

permanent residents enumerated in the 2001 census is not known

at the time of writing. The best estimate is approximately 290,000 .

${ }^{3}$.Originally, the spouse of a person issued a temporary

employment authorization was not permitted to work in Canada.

When, in 1998, the government decided to encourage the entry of

information technology experts and soft-ware developers, this rule

was relaxed (CIC Performance Report, March,1999,p.9).

${ }^{4}$. Under the terms of Canada $=\mathrm{s}$ Immigration Act there are several

types of removal order. In 1998 thee were 2,365 departure orders,

2,956 deemed deportations, 1,743 deportations and 898 exclusion

orders. NB If a person is issued a departure order but does not

leave Canada within 30 days and does not confirm the departure

with CIC, the departure order automatically becomes a Adeemed

deportation A order. The number of people removed from Canada 
Anthony H. Richmond

in 1998 was 8,012 of whom $62 \%$ were failed refugee claimants ,and 22\% were criminals ( CIC Enforcement Fact Sheet, April 1999). By October 2000 there were still 91Chinese detainees in British Columbia some of whom were on hunger strike. It was reported that 40 or more were about to be deported.

${ }^{5}$.Castells (1996) prefers the term Atime space compression@.He notes the increasing interdependence of the labour force on a global scale and associated cross-border networks

${ }^{6}$. Attitudes and values may be internalized as a result of the degree of time-space distanciation actually experienced. Hypothetically, one would expect a small negative correlation between high levels of distanciation and greater social distance i.e. closer communication would lead to a reduction in prejudice. However, there would be many exceptions to this, depending upon intervening variables, such as perceived economic competition.

${ }^{7}$.Since its establishment the Canadian Immigrant Investment 
Program generated over $\$ 4$ billion in investment. Commencing April,1999 a redesigned version required applicants to have a net worth of at least $\$ 800,000$ and to invest a minimum of $\$ 400,000$ Between four and six thousand investors entered Canada 1996-98.( CIC Performance Report, March 1999).

${ }^{8}$. Laxer (1995:299) notes that "While millions of desperate migrants are turned back at borders and many others endure exploitation and abuse as illegal aliens, rich foreigners have recently been give special treatment". He cites Canada, the USA and Australia, who admit entrepreneurs for a price ranging up from a quarter of million dollars.

${ }^{9}$. The 1951 UN Convention on Refugees (as amended in New York,1967) was a product of the "Cold War", and is inadequate for today's political and economic crises. The Convention, as interpreted by Canada and other countries, places the onus on the individual seeking asylum to prove that they would be personally 
Anthony H. Richmond

at risk, if returned to their former country. Only a small proportion of all asylum seekers, globally, are successful in their claims, and there is enormous variation from one receiving country to another in acceptance rates. (Hathaway,1996).

${ }^{10}$.In the Canadian case, the number of interceptions of improperly documented passengers increased from approximately 3,200 in 1993 to over 6,000 in 1998 . At the same time the number actually reaching Canada $=\mathrm{s}$ ports of entry declined 6\% between 1997 and 1998.

${ }^{11}$. An additional 3.8 million Palestinians were covered by a separate mandate of the U.N. Relief and Works Agency.

12. Canada introduced Bill $\mathrm{C} 31$ which died when an election was called in October,2000. A revised version (Bill C11) was subsequently passed in the House of Commons. At the time of writing it was before the Senate. Following the terrorist attacks on the USA, it is expected that the new Canadian immigration law will strengthen the powers of immigration officers to refuse entry to 
Canada on grounds of criminality, security risk, or forged or inadequate identity documents. It will impose higher maximum penalties for human smuggling, and place the responsibility on airlines to identify and inform CIC concerning passengers who may be inadmissible to Canada. New identity cards will be issued to landed immigrants. It remains to be seen what further steps will be taken to protect the North American Aperimeter@ and facilitate traffic across the Canada/USA border.

13. For a detailed account of recent practice and suggested reforms of refugee law see Hathaway and Dent (1995) and Hathaway (1996).

${ }^{14}$.The Canadian acceptance of Convention refugees compares with a rate of $22 \%$ in Britain, although the latter country gave Aexceptional leave to remain@ to a further 41\% in 1999. (Richmond,2000:36) 